Vol.3 No.2 Hal. $78-83$

September 2020
BEST JOURNAL

(Biology Education,science \& Technolog̉y)

Fakultas Keguruan dan IImu Pendidikan
ISSN (Print) : $2614-8064$

ISSN (Online): $2654-4652$

\title{
Meningkatkan Kemampuan Motorik Kasar Anak Berkebutuhan Khusus Melalui Kegiatan Melempar Bola Pada Olahraga Boccia Dengan Pendekatan Hots Di SMALB - D1 YPAC Surakarta
}

\author{
Ulwa Humairok Gandes Luwes
}

Guru Sekolah Luar Biasa YPAC Surakarta,

\author{
Pendidikan Luar Biasa Universitas Sebelas Maret Surakarta
}

ulwahumairok@gmail.com

\begin{abstract}
ABSTRAK
Penelitian ini bertujuan untuk mengetahui apakah penggunaan media olahraga Boccia dapat meningkatkan kemampuan motorik kasar melempar bola di SMALB - D1 YPAC Surakarta. Penelitian ini merupakan penelitian tindakan kelas dengan analisis deskriptif kolaboratif. Penelitian dilaksanakan di SMALB - D1 YPAC Surakarta dengan subyek berjumlah 5 siswa yang terdiri dari 4 laki-laki dan 2 perempuan. Pada kemampuan awal terlihat 1 siswa yang melakukan gerak melempar bola. Pada Siklus I sudah mengalami kemajuan menjadi 3 siswa melempar bola dengan baik. pada Siklus II tingkat keaktifan siswa terpenuhi. Dengan diberikan media olahraga bocid, siswa sudah aktif mengikuti kegiatan melempar bola, sehingga indikator keaktifan siswa telah terpenuhi.
\end{abstract}

Kata Kunci : Motorik Kasar, Melempar Bola, Boccia

\begin{abstract}
This study aims to determine whether the use of Boccia sports media can improve gross motor skills in throwing a ball at SMALB - D1 YPAC Surakarta. This research is a classroom action research with collaborative descriptive analysis. The research was conducted at SMALB - D1 YPAC Surakarta with 5 students as subjects consisting of 4 boys and 2 girls. In the initial ability, it was seen that 1 student was throwing the ball. In Cycle I, there were 3 students throwing the ball well. in Cycle II the level of student activity was fulfilled. Given the bocid sports media, students have been actively participating in ball throwing activities, so that the indicators of student activity have been fulfilled.
\end{abstract}

Keywords : Gross Motoric, Ball Throwing, Boccia 
Luwes Ulwa Humairok G : Meningkatkan Kemampuan Motorik Kasar Anak Berkebutuhan Khusus Melalui Kegiatan Melempar Bola Pada Olahraga Boccia Dengan Pendekatan Hots di SMALB - D1 YPAC Surakarta.

\section{PENDAHULUAN}

\section{Latar Belakang}

Upaya peningkatan kualitas pendidikan di Indonesia tidak pernah berhenti. Berbagai terobosan baru terus dilakukan oleh pemerintah melalui Direktorat Pembinaan Guru Pendidikan Menengah dan Pendidikan Khusus. Upaya itu antara lain dalam pengelolaan sekolah, peningkatan sumber daya tenaga pendidikan, pengembangan / penulisan materi ajar, serta pengembangan paradigma baru dengan metodelogi pengajaran. Guru merupakan salah satu faktor yang cukup berpengarus langsung dalam peningkatan mutu tersebut. guru merupakan jabatan yang paling dipilih berdasarkan prinsip-prinsip vokasional, dalam hal aspek psikologis menjadi faktor untuk melaksanakan tugas dan tanggung jawabnya sebagai pendidik (Oemar Hamalik, 2002 : 24). Boccia adalah permainan kompetitif yang dapat dimainkan satu-satu, berpasangan, atau dalam tim tiga. Boccia dimainkan dalam lapangan, obyek dari permainan ini adalah untuk membuang atau melempar bola sedekat mungkin dengan bola target. Ada tiga warna bola dalam Boccia. Putih, merah dan biru. Bola putih merupakan bola jack, bola pertama yang dilempar oelh salah satu tim. Bola ini yang akan menjadi sasaran lempar enam bola merah dan enam bola biru yang dipegang para tim. Bola yang terdekat dengan jack yang dihitung point. Wasit akan mengukur jarak bola terdekat dengan jack menggunakan alat ukur yang berbentuk mirip jangka.Tangan merupakan hal yang paling utama dalam melakukan berbagai aktivitas sehari-hari. Tanpa tangan seseorang akan merasa kesulitan untuk menjalankan aktivitas sehari-hari. Kemampuan melempar bola pada olahraga.

\section{Perumusan Masalah}

Program khusus untuk meningkatkan pengembangan diri meliputi berbagai macam Orientasi Mobilitas Sosial Komunikasi untuk anak dengan gangguan penglihatan. Pengembangan komunikasi presepsi bunyi dan irama untuk anak dengan gangguan pendengaran. Dan pengembangan interaksi komunikasi untuk anak dengan gangguan Autis, serta pengembangan Bina Perilaku dan Sosial untuk anak dengan gangguan Sosial dan Perilaku. SMALB - D1 YPAC Surakarta merupakan sekolah yang menangani anak yang mengalami gangguan motorik

\section{Tujuan Penelitian}

Peningkatan mutu penididkan perlu perubahan pola fikir posistif yang digunakan sebagai landasan pelaksanaan kurikulum. Pendidikan anak berkebutuhan khusus pada hakekatnya berbeda dengan pendidikan untuk anak-anak normal, karena pendidikan bagi anak berkebutuhan khusus disamping memberikan pendidikan melalui materi pokok dalam setiap mata pelajaran, juga memberikan pendidikan dalam bentuk layanan pendidikan khusus. Bahkan layanan pendidikan khusus ini berbeda-beda antara jenis kekhususan / keldinan yang satu dengan yang lain. Menurut struktur kurikulum pendidikan khusus dalam standar isi yang dikembangkan oleh Badan Standar Nasional Pendidikan. Layanan khusus bagi anak-anak berkebutuhan khusus itu dimuat dalam apa yang disebut "Program Khusus". Gangguan Motorik tersebut adalah seseorang yang memiliki kelainan fisik dan gangguan Fungsi Fisik. Kelainan Fisik merupakan kelainan bentuk tubuh yang berhubungan dengan tulang, sendi dan otot. Misalnya anak menyandang kelainan amputie, kelainan bentuk tubuh dan organ gerak serta diskolasi sendi. Sedangkan gangguan fungsi fisik adalah seseorang yang memiliki kondisi fisik normal tetapi memiliki fungsi fisiknya yang terganggu atau motoriknya terganggu. Misalnya penyandang Polio dan Cerebal Palsy. Boccia merupakan salah satu cabnag olahraga khusus bagi Penyandang Cerebal Palsy. Boccia merupakan 
Luwes Ulwa Humairok G : Meningkatkan Kemampuan Motorik Kasar Anak Berkebutuhan Khusus Melalui Kegiatan Melempar Bola Pada Olahraga Boccia Dengan Pendekatan Hots di SMALB - D1 YPAC Surakarta.

permainan yang membutuhkan koordinasi mata dan tangan, Boccia merupakan salah satu alat rehabilitasi anak-anak di SMALB - D1 YPAC Surakarta.

\section{Manfaat Penelitian}

Boccia dapat meningkatkan koordinasi mata dan tangan. Boccia masih terdengan asing bagi sebagian orang, maka dari itu penulis melakukan penelitian guna mengkaji hasil peningkatan kekuatan otot tangan untuk melempar bola pada olahraga Boccia dengan metode HOTS (koordinasi mata dan tangan).

\section{METODE PENELITIAN}

\section{Sumber Data.}

Sumber data dalam penelitian ini digali dari berbagai sumber, yaitu :

a. Data kuantitatif

Data kuantitatif dalam penelitian ini perubahan nilai post tes matematika pada setiap siklus.

b. Data kualitatif

Data kualitatif data penelitian ini diperoleh dari hasil wawancara dan dokumen dokumen yang mendukung

\section{Cara Mengumpulkan Data}

cara pengumpulan data dalam penelitian ini adalah berupa observasi langsung dan tes.

1. Observasi Langsung

Observasi langsung adalah observasi yang dilakukan oleh eh observer secara langsung kepada konsumen responden sebagai objek penelitian. Observasi dilakukan secara formal di lapangan pada saat proses belajar mengajar sedang berlangsung untuk mengamati segala aktivitas siswa.

2. Tes

Metode ini dilakukan untuk mengukur kemampuan siswa setelah mengikuti proses belajar mengajar. Tes ini berupa serangkaian pernyataan yang diberikan kepada siswa.

\section{HASIL DAN PEMBAHASAN}

A. Pembahasa tentang perkembangan Motorik Kasar

\section{Pengertian Motorik Kasar}

Motorik Kasar adalah kemampuan gerak tubuh yang menggunakan otot-otot besar, sebagian besar atau seluruh anggota tubuh Motorik Kasar diperlukan agar anak dapat duduk, menendang, berlari, naik turun tangga dan sebagainya. Motorik kasar merupakan usaha menggerakkan berbagai gerakan tubuh atas perintah otak dan mengatur gerakan badan terhadap macam-macam perngaruh dari luar dan dalam. Unsur-unsur yang mempengaruhi keterampilan motorik yaitu kekuatan korrdinasi, kecepatan, keseimbangan, dan kelincahan. Endang Rini Sukamti (2007 : 72) menyatakan bahawa gerak motorik kasar terbagi menjadi tiga, diantaranya gerak keterampilan non lokomotor, gerakan lokomotor, dan gerakan manipulatif. Gerakan non lokomotor adalah aktivitas gerak tanpa memindahkan tubuh ketempat lain. Contoh gerakan non lokomotor mendorong, melipat, menarik, dan membungkuk. Gerakan lokomotor adalah gerak yang memindahkan tubuh satu ketempat lain. Contoh gerakan non lokomotor brlari, melompat, jalan. Dan gerakan manipulatif adalah aktivitas gerak manipulasi benda. Contohnya gerakan manipulatif adalah melempar, menggiring, menagkap dan menendang. Perkembangan memori pada anak memerlukan koordinasi antara otot-otot untuk 
Luwes Ulwa Humairok G : Meningkatkan Kemampuan Motorik Kasar Anak Berkebutuhan Khusus Melalui Kegiatan Melempar Bola Pada Olahraga Boccia Dengan Pendekatan Hots di SMALB - D1 YPAC Surakarta.

keterampilan gerakannya, misalnya melempar bola dalam jarak $\pm 100 \mathrm{~cm}$ perlu kekuatan otot tangan dan konsentrasi yang baik. Gerakan motorik kasar membutuhkan aktivitas otot tangan, kaki, dan seluruh tubuh anak. Ada beberapa kegiatan yang dapat mengembangkan gerakan motorik anak. Misalnya aktivitas berjalan diatas papan titian, melompat tali, senam, renang, melempar bola dan sebagainya. Hal tersebut selain dapat membuat senang anak juga dapat melatih anak untuk percaya diri.

2. Fungsi Perkembangan Motorik Kasar

Fungsi perkembangan Motorik Kasar menurut Depdiknas, 2008 :2 sebagai berikut

a. Melatih kelenturan dan koordinasi otot jari dan tangan.

b. Memacu pertumbuhan dan perkembangan fisik/motorik, rohani dan kesehatan anak.

c. Membentuk, membangun dan memperkuat tubuh anak.

d. Melatih keterampilan/ketangkasan gerak dan berfikir anak.

e. Meningkatkan perkembangan emosional anak.

f. Meningkatkan perkembangan sosial anak.

g. Menumbuhkan perasaan menyenangi dan memahami manfaat kesehatan pribadi.

3. Faktor Perkembangan Motorik

Menurut Sumantri (2005 : 146), faktor yang mempengaruhi perkembangan Motorik anak antara lain :

a. Perkembangan Anatomi Anak

Ditunjukkan dengan adanya perubahan kuantitas, pada struktur tulang belulang, proporsi tinggi kepala dan badan secara keseluruhan. Perkembangan motorik anak diperlihatkan dengan bertambahnya jumlah tulang belulang yang berpengaruh pada semakin meningkatnya proporsi tinggi kepaladitunjukkan dengan adanya perubahan kuantitas, pada struktur tulang belulang, proporsi tinggi kepala dan badan secara keseluruhan. Perkembangan motorik anak diperlihatkan dengan bertambahnya jumlah tulang belulang yang berpengaruh pada semakin meningkatnya proporsi tinggi kepala dan berat badan pada anak..

b. Perkembangan Fisiologi

Ditandai dengan adanya perubahan secara kuantitatif, kualitatif dan fungsional dari sistem kerja hayat. Seperti kontraksi otot peredaran darah dan pernafasan, persyarafan, produksi, kelenjar dan pencernaan. Pada anak otot berfungsi sebagai pengontrol motorik dan denyut jantung frekuensinya sekitar 140 denyut permenit. Seiring dengan bertambahnya usia anak, maka fungsi organ tubuh anak berubah menjadi lebih matang.

Berdasarkan data awal yang diperoleh guru setelah melakukan praktek gerak motorik kasar melempar bola, diperoleh bahwa dari 5 siswa yang memperoleh nilai diatas 70 hanya satu siswa.hal ini menunjukkan bahwa keinginan siswa untuk melakukan gerak motorik kasar melempar bola sangat rendah. Setelah dilakukan tindakan pada siklus I, mengalami peningkatan menjadi 3 siswa atau 60\%. Pada siklus II tingkat kemahiran siswa sudah mencapai $100 \%$. Data perkembangan tingkat ketuntasan gerak motorik kasar melempar bola dapat disajikan pada tabel berikut : 
Luwes Ulwa Humairok G : Meningkatkan Kemampuan Motorik Kasar Anak Berkebutuhan Khusus Melalui Kegiatan Melempar Bola Pada Olahraga Boccia Dengan Pendekatan Hots di SMALB - D1 YPAC Surakarta.

Tabel tingkat ketuntasan dari awal sampai Siklus II.

\begin{tabular}{|l|l|l|l|l|}
\hline No & Kode Subjek & Nilai Awal & Siklus I & Siklus II \\
\hline 1. & YG & 75 & 80 & 85 \\
\hline 2. & VN & 60 & 75 & 80 \\
\hline 3. & RZ & 50 & 75 & 80 \\
\hline 4. & VF & 50 & 55 & 75 \\
\hline 5. & WY & 50 & 55 & 75 \\
\hline & Tingkat ketuntasan & $\mathbf{2 0} \%$ & $\mathbf{6 0} \%$ & $\mathbf{1 0 0} \%$ \\
\hline
\end{tabular}

Dari tabel di atas dapat ditarik kesimpulan bahwa untuk meningkatkan kemampuan gerak motorik kasar pada siswa, diperlukan alat peraga atau permainan yang menarik. Penyampaian materi pembelajaran dilakukan dengan didukung dengan demonstrasi penggunaan alat peraga terlupa olahraga Boccia. Dengan demikian hipotensi yang berbunyi "Peningkatan Kemampuan Motorik Kasar anak berkebutuhan khusus melalui kegiatan melempar bola pada olahraga Boccia dengan pendekatan HOTS di SMALB - D1 YPAC Surakarta" dapat diterima kebenarannya.

\section{KESIMPULAN}

Berdasarkan Pembahasan Penelitian tindakan kelas ini dapat diambil kesimpulan, bahwa olahraga atau permainan Boccia dapat meningkatkan kemampuan gerak anak motorik kasar melempar bola anak berkebutuhan khusus siswa SMALB - D1 di Surakarta. Hal ini ditunjukkan dengan meningkatnya ketuntasan gerak motorik kasar siswa yang telah mengikuti kegiatan praktek melempar bola. Hasil tes Siklus I dan Siklus II menunjukkan bahwa penguasaan konsep melempar bola pada siswa semakin meningkat. Selain dapat meningkatkan semangat dan hasil belajar, pembelajaran dengan olahraga Boccia merupakan hal yang baru bagi siswa sehingga dapat meningkatkan motivasi belajar dan siswa menjadi lebih bersemangat untuk berprestasi.hal ini ditunjukkan dengan hasil pengamatan bahwa tingkat keaktifan siswa dalam melakukan gerak motorik kasar melalui peningkatan dari mulai siklus I sampai siklus II.

\section{DAFTAR PUSTAKA}

Abdul Salim CH. 2006. Makalah : Hambatan dan kebutuhan anak gangguan motorik. Jakarta : direktorat P2TK dan KPT. Dikti. Depdiknas.

Abdul Salim CH. 1996. Pendidikan Bagi Anak Cerebral Palsy. Jakarta : Ditjen Dikti. Depdikbud.

Abdul Salim CH. 1995. Fisioterapi dan Gina Gerak. Surakarta : UNS Press.

Ari Kunto, Suharsimi. 1997. Prosedur penelitian suatu pendekatan praktek. Jakarta: Rineka Cipta.

Asrori. M. 2007. Penelitian Tinakan Kelas. Bandung : Wacana Prima.

Dar Mansyah. 2006. Tekhnik Belajar yang Menyenangkan. Jakarta : Rineka Cipta.

Depdiknas. 2008. Kurikulum Tingkat Satuan Pendidikan. Jakarta : Dikmenum Depdiknas.

Endang Rini Sukamti. 2007. Pengembangan Motorik Diktat. Yogyakarta : FIK UNY.

Fatimah Suroko, NY. 2013. Orang Tua Special untuk Anak Special. Jakarta : YPAC Nasional.

Hamalik Oemar. 2002. Psikologi Belajar Mengajar. Bandung Sinar Baru Algesindo. Miles Mettew B dan A. Ichael Hubedman. 1992. Analisis Data Kualitatif. Jakarta : UI Press. 
Luwes Ulwa Humairok G : Meningkatkan Kemampuan Motorik Kasar Anak Berkebutuhan Khusus Melalui Kegiatan Melempar Bola Pada Olahraga Boccia Dengan Pendekatan Hots di SMALB - D1 YPAC Surakarta.

Sumantri. 2005. Model Pengembangan Keterampilan Motorik Anak Usia Dini. Jakarta : Direktorat Pembinaan Pendidikan Tenaga Kependidikan dan Ketenagaan Perguruan Tinggi.

Sutama. 2015. Metode Penelitian Pendidikan (Kuantitatif, Kualitatif, PTK R\&D). Surakarta : Fairus Media.

W.J.S. Poerwa Darminto. 2002. Kamus Umum Bahasa Indonesia. Jakarta : Balai Pustaka.

\begin{tabular}{|l|l|l|l|}
\hline Accepted Date & Revised Date & Decided Date & Accepted to Publish \\
\hline 06 Agustus 2020 & 08 Agustus 2020 & 11 Agustus 2020 & Ya \\
\hline
\end{tabular}

